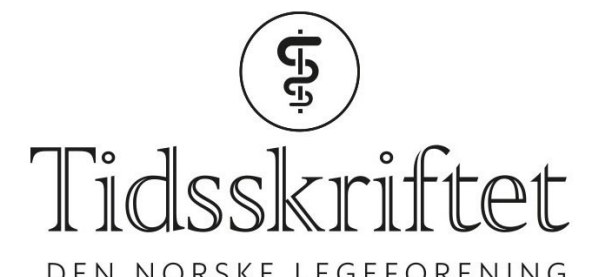

DEN NORSKE LEGEFORENING

\title{
Organoider som modell for hjernens utvikling
}

FRA ANDRE TIDSSKRIFTER

RUTH HALSNE

Tidsskriftet

En tredimensjonal modell av forhjernen gjenskaper utviklingen av senteret for kognitive funksjoner.

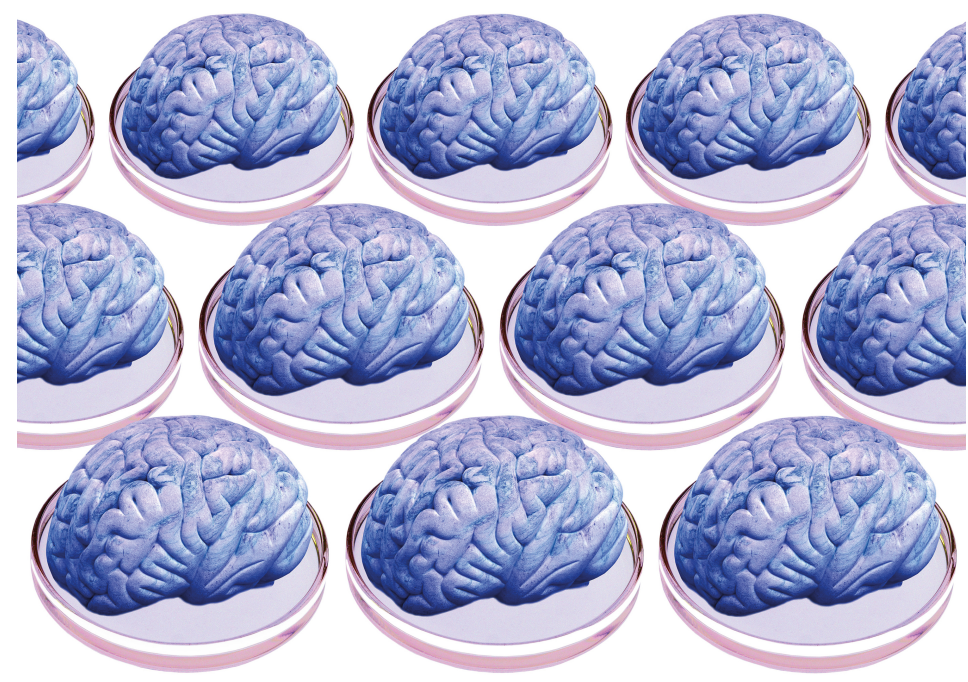

Illustrasjon: Science photo library / NTB Scanpix

For å kunne studere hjernens utvikling hos mennesker har forskere i USA utviklet en tredimensjonal modell av den humane forhjernen basert på pluripotente stamceller (1). I modellen fulgte man utviklingen over et tidsrom på 20 måneder og undersøkte hvordan kromatinmønsteret og genuttrykk varierte. Dataene ble brukt til å kartlegge de molekylære signalene som styrer denne utviklingen. Man undersøkte så om proteinekspresjonen kunne bekrefte funnene. Målet var å kartlegge gener og genetiske varianter som er vist å være assosiert med schizofreni og autisme.

- Hos pattedyr er utvikling av hjernen generelt vanskelig å studere, ettersom denne skjer in utero, sier Viola Lobert, som er forsker ved Senter for kreftcellereprogrammering, Universitetet i Oslo. Etiske hensyn gjør at mye av den informasjonen vi har om hjernens utvikling kommer fra modellorganismer, bl.a. mus. Det som gjør denne studien unik, er at forskningsgruppen har klart å lage en human modell av forhjernen som kan modifiseres, observeres og dyrkes over lang tid. Denne type arbeid fører oss nærmere en forståelse av hva som gjør oss til mennesker, sier Lobert. 
- Studien viser det revolusjonerende ved å dyrke organoider og å bruke organoider som komplekse modeller, i dette tilfellet fra forhjernen, for å studere utvikling av kognitive funksjoner, sier Lobert.

- Andre studier har vist at organoider fra tarmen kan gi kunnskap om hvordan pasienter reagerer på ulike legemidler. Man kan blant annet bruke disse til å teste legemidler mot cystisk fibrose, og organoider fra svulstvev fra en pasient kan brukes til å predikere pasientens respons på legemidler mot kreft. Det vil være spennende å se om man kan bruke organoidene som ligner forhjernen, til å utvikle diagnostiske metoder eller legemidler mot nevrologiske sykdommer, sier Lobert.

LITTERATUR:

1. Trevino AE, Sinnott-Armstrong N, Andersen J et al. Chromatin accessibility dynamics in a model of human forebrain development. Science 2020;367: 404-14. [PubMed][CrossRef]

Publisert: 29. juni 2020. Tidsskr Nor Legeforen. DOI: 10.4045/tidsskr.20.0337

(C) Tidsskrift for Den norske legeforening 2020. Lastet ned fra tidsskriftet.no 